\title{
O PAI EM PSICANÁLISE: INTERROGAÇÓES ACERCA DAS INSTÂNCIAS REAL, SIMBÓLICA E IMAGINÁRIA DA FUNÇÃO PATERNA
}

THE FATHER IN PSYCHOANALYSIS: INTERROGATIONS ABOUT REAL, SYMBOLIC AND IMAGINARY INSTANCES

OF THE PATERNAL FUNCTION

EL PADRE EN PSICOANÁLISIS: INTERROGACIONES RESPECTO A LAS INSTANCIAS REAL, SIMBÓLICA E IMAGINARIA DE LA FUNCIÓN PATERNA

\author{
Mariana Kraemer Betts* \\ Amadeu de Oliveira Weinmann ** \\ Analice de Lima Palombini***
}

\section{Resumo}

A pergunta acerca do pai permanece central na experiência analítica desde Freud até os dias de hoje. O presente trabalho tem como objetivo discorrer sobre o papel que exercem as diferentes instâncias da função paterna - pai real, pai simbólico, pai imaginário e Nome-do-Pai - na constituição de um sujeito, articulando-as com um caso clínico. Para tanto, parte-se da escrita de tal experiência clínica e dos interrogantes suscitados por ela. A seguir, buscamos delinear alguns desdobramentos que tais conceitos tiveram na obra de Lacan, realçando que, se por um lado a teorizaçáo da problemática paterna esteve em permanente deslocamento ao longo dos seminários desse psicanalista, por outro a articulação entre seus distintos elementos permaneceu como uma exigência conceitual irrevogável. A interdependência das diferentes instâncias com relação ao que elas operam na estruturação do sujeito e a formulaçáo lacaniana da estrutura borromeana RSI apontam para a importância clínica de considerar as instâncias paternas de forma enlaçada.

Palavras-chave: função paterna; RSI; Nome-do-Pai.

\footnotetext{
* Universidade Federal do Rio Grande do Sul, Porto Alegre, RS, Brasil.

** Universidade Federal do Rio Grande do Sul, Porto Alegre, RS, Brasil.

*** Universidade Federal do Rio Grande do Sul, Porto Alegre, RS, Brasil.
} 


\section{Abstract}

The question about the father in the analytical experience remains central from Freud until today. The objective of the present article is to discuss the role that the different instances of the paternal function - the real father, the symbolic father, the imaginary father and the Name-of-the-Father - have in the constitution of the subject and in a clinical practice. The article begins with the writing of a clinical experience and the questions it brings forth. Next, we outline some of the developments that such concepts had in Lacan's work, highlighting the fact that while his theorization of the paternal problematic shifted permanently throughout his seminars, the articulation between its different elements remained an irrevocable conceptual requirement. The interdependence of these different instances in relation to what they operate in the structuring of the subject and the lacanian formulation of the Borromean RSI point to the clinical importance of considering the paternal instances in an interlaced way.

Keywords: paternal function; RSI; Name-of-the-Father.

\section{Resumen}

La pregunta acerca del padre sigue siendo central en la experiencia analítica, desde Freud hasta los días vigentes. El presente ensayo tiene como propósito discurrir respecto al papel que ejercen las distintas instancias de la función paterna - padre real, padre simbólico, padre imaginario y Nombre-del-Padre - en la constitución de un sujeto, articulándolas a un caso clínico. Para tal se parte de la escrita de dicha experiencia clínica y de los interrogantes suscitados por ella. A continuación, tratamos de señalar algunos desplazamientos que han tenido estos conceptos en la obra de Lacan, indicando que, si por un lado, la teorización de la problemática paterna se movió constantemente a lo largo de los seminarios de ese psicoanalista, por otro, la relación entre sus distintos elementos se mantuvo una cuestión conceptual irrevocable. La interdependencia de las distintas instancias respecto a lo que operan en la estructuración del sujeto y la formulación lacaniana de la estructura RSI borromeana apuntan la importancia clínica de considerar a las instancias paternas de forma enlazada.

Palabras clave: función paterna; RSI; Nombre-del-Padre.

A experiência clínica em psicanálise convoca à pesquisa. E a pesquisa psicanalítica parece referir-se justamente à escrita dessa experiência, ou melhor, à escrita daquilo que nela nos interroga. Para a transmissão de uma experiência, é necessário que haja o endereçamento de um enigma, mas também que esse 
endereçamento passe de um semelhante, imaginário, para o Outro da cultura, simbólico. É em uma báscula entre o impessoal e o pessoal que a transmissão opera. Isso implica produzir um enigma endereçado ao Outro que transmita uma falta. Assim, estamos falando de um ato que produza um recorte, algo singular, próprio, mas enlaçado ao Outro (Costa, 2001).

Uma vez que a pesquisa consiste em uma forma singular de perguntar-se pela clínica, no presente artigo partimos de interrogantes produzidos pela experiência analítica a fim de pensar a problemática da função paterna em Lacan no que diz respeito aos tempos de estruturação do sujeito e também ao trabalho clínico, abordando os conceitos de pai (no que se refere aos registros real, simbólico e imaginário) e de Nome-do-Pai. Embora, na infância, essas instâncias ou facetas do pai tenham um relevo singular, as experiências clínicas que suscitam este trabalho não se restringem à clínica com crianças. Como diz Flesler (2007), mais que idade, o sujeito tem tempos, e a escuta do psicanalista aponta para o sujeito.

Nesse sentido, a pergunta "o que é ser um pai?" também aponta para a questão da transmissão: o que transmite um pai? Que lugar na função paterna ocupam e exercem pai real, pai simbólico e pai imaginário nisso que se trata de transmitir para a constituição do sujeito?Freud afirma a preeminência do pai na constituição da realidade psíquica. Em "A novela familiar do neurótico", Freud (1909/2006) aponta que a neurose tem por traço característico uma atividade imaginativa de particular intensidade que se manifesta desde os primeiros jogos infantis e domina as relaçóes familiares por volta da época pré-puberal. A imaginação da criança dedica-se a substituir os pais menosprezados por outros mais enaltecidos. Quando a criança passa a compreender que há vinculação sexual entre o pai e a mãe e que pater semper incertus est, enquanto que a mãe é certíssima, a novela familiar do neurótico se restringe. A criança já não duvida da origem materna e se limita a exaltar o pai em sua novela. Essa exaltaçáo da criança, que promove uma imagem de um pai poderoso e digno de ser admirado, é relativa à funçấo do pai imaginário ou do pai como imagem. Este, por sua vez, recobre o real do pai - concernente ao pater semper incertus est, mencionado por Freud -, ou seja, a impossibilidade de saber referente ao verdadeiro da paternidade.

Lacan situou a interrogação "o que é um pai?” como central e não resolvida na experiência analítica, retomando a questão com a introdução dos conceitos Nome-do-Pai e nomes do pai (Porge, 1998). Tratando-se de um tema que no ensino e na transmissão da psicanálise ocupou um lugar destacado e, pode-se dizer, bastante conturbado, o desafio que assumimos neste artigo é o de transmitir algo da importância de se considerar de forma enlaçada as diferentes instâncias paternas através da escrita narrativa de uma experiência clínica. Tal experiência 
não somente deu lugar a inúmeros questionamentos referentes, principalmente, ao lugar da função paterna e das dimensóes implicadas na constituição de um sujeito, mas convocou, além disso, a pensar o que se passa quando os pais da realidade encontram dificuldades para encarnar essas funções.

O encontro com Soledad, de 19 anos, e seu filho Pablo, de 4 anos, deu-se no marco de um atendimento psicanalítico. Vêm encaminhados pela psicopedagoga do jardim de infância. Soledad conta que Pablo tem muitos medos e sérias dificuldades para falar e caminhar: "como uma criança de dois anos, e tem quatro", informa, e o compara a outra criança do jardim, que tem síndrome de Down. A mãe diz que não brinca com o menino, que não tem paciência com ele e que lhe custa aproximar-se dele. Conta, ainda, que Pablo tem "dificuldade para brincar ou envolver-se na brincadeira com outras crianças".

Soledad se separou do pai de Pablo quando este tinha três meses de idade. Desse pai nada mais foi dito. Então, foram viver na casa da família materna, com a mãe e os irmãos de Soledad, onde Pablo passou a dormir sempre com sua mãe e onde não tinha espaço para brincar - o que não se referia apenas ao espaço físico. Soledad conta que, há cerca de um mês, estão vivendo com seu novo parceiro, Gonzalo, em outra casa, onde Pablo tem sua própria cama e espaço para seus brinquedos. Há um mês dorme sozinho.

$\mathrm{Na}$ entrevista em que se apresenta, Pablo sorri todo o tempo. Parece desconectado, imotivado, mas, quando a terapeuta lhe dirige a palavra, brincando com o que diz, Pablo, embora não fale, responde com o riso. Ao the serem oferecidos brinquedos, Pablo apenas na metade do atendimento se dirige a eles, interessando-se pelos carros; senta-se no chão e passa a mover um deles para frente e para trás. A terapeuta toma outro carro e começa a fazer sons e movimentos. Então arma-se algo de um jogo incipiente: ele passa a fazer, em espelho, sons e movimentos com seu carro e a solicitar à terapeuta, com gestos e sons, que os faça novamente com o seu.

Em entrevista realizada apenas com a mãe, ela conta que negou a gravidez. Diz que Pablo "custou a caminhar" e "demorou a balbuciar". Refere que no ano anterior começou a notar diferenças em relação a outros meninos. Ao longo desses atendimentos, Soledad começa a desdobrar algumas questóes referentes à entrada de Gonzalo na cena familiar. Com ele, passa a compreender que precisa ensinar coisas ao "nenê": "não sabia que a um bebê tinha que lhe falar". Gonzalo lhe diz que tem que "se separar, se desgrudar" de Pablo, "não estar tanto em cima do menino". Gonzalo brinca com Pablo. Faz, ainda, com que a mãe permita que ele vá à rua brincar com os vizinhos, apesar do temor dela em relação a isso. Soledad diz que o marido "tem muita paciência" com o menino, "ensina" Pablo e 
este "o escuta, obedece, segue". A palavra de Gonzalo interessa a Pablo. E Pablo lhe tem respeito.

Soledad diz que há algumas semanas "Pablo está mais tranquilo, não sei se porque antes não havia lugar na casa da minha mãe. Tem seu espaço agora". Antes, o via "nervoso, sobressaltado, inquieto". "É tranquilo, tímido, lhe custa adaptar-se às pessoas, tem medos". Porém, apesar de toda a dificuldade que ainda apresenta, "agora tem amigos para brincar".

Não havia espaço para Pablo na casa da mãe de Soledad; não havia tampouco lugar para que Soledad, além de filha, fosse mãe. Ou seja, não lhe era possível exercer uma função materna. Soledad não sabia que com uma criança é preciso falar. Também não havia qualquer separação entre mãe e filho. Em vista disso, estavam dificultadas, senão impossibilitadas, uma série de funçóes: seja a do Outro primordial, que traz à criança a linguagem, seja a do outro especular do transitivismo, funçâo esta necessária para a construção simbólico-imaginária do corpo do sujeito em estruturação (Bergès \& Balbo, 2002). Da mesma forma, também o pai não era introduzido pela palavra da mãe, quer dizer, não era introduzido um lugar terceiro onde a palavra pudesse ter efeito. Assim, não era à toa que Pablo apresentava dificuldades importantes para falar, para caminhar e para brincar.

Como pensar os efeitos produzidos a partir da entrada de Gonzalo? O que foi introduzido por ele? Que funçóes simbólica, imaginária e real esse homem encarnou para máe e filho? Tais questôes, que dizem da funçáo do pai e de suas instâncias na constituição do sujeito, remetem-nos às leituras e às formulaçóes que a esse respeito propôs Jacques Lacan. De acordo com Porge (1998, p. 7), "para Lacan, o sujeito está 'encurralado' entre o simbólico, o imaginário e o real e dividido entre saber e verdade. $\mathrm{O}$ pai existe nos intervalos destes termos, contribuindo para sua distinção".

A função paterna foi introduzida por Lacan através de dois eixos: um referente ao Nome-do-Pai; e outro, ao ternário pai simbólico, pai real e pai imaginário (Porge, 1998). Em 1951, a propósito do caso do Homem dos lobos, de Freud, Lacan utiliza o termo Nome-do-Pai pela primeira vez, mas apenas refere entáo que é um termo proveniente da religiáo ${ }^{1}$. Ao se valer desse termo para analisar o Édipo, Lacan inverte a lógica de Freud, o qual situara Deus como uma figura posterior ao assassinato do pai da horda primitiva, isto é, como signo de uma tentativa de expiaçáo do assassinato primordial. Aproximando-se do Nome de Deus, o Nome-do-Pai se desloca e se diferencia da noção de pai em "Totem e tabu".

No Seminário As psicoses, de 1955-1956, no qual Lacan debruça-se sobre outro caso de Freud, a importância do significante Nome-do-Pai aparece ligada a 
sua inoperância em Schreber. A estrutura da psicose é determinada pela foraclusão desse significante e o desencadeamento de um surto, por uma injunção que a confronte. $\mathrm{O}$ significante do pai vem relacionado com a introdução da série das gerações, de uma ordenação na linhagem (Porge, 1998).

No que se refere ao outro eixo - o do ternário - da função paterna, Lacan faz uso das categorias real, imaginário e simbólico, distinguindo seus papéis, tanto na interpretação que faz do caso do Homem dos lobos, em 1951, quanto na análise que realiza do caso do Homem dos ratos, também de Freud, em 1953. No seminário A relação de objeto, de 1956-1957, o ternário pai imaginário, pai simbólico e pai real é prevalente; o termo Nome-do-Pai não é mais colocado à frente, sendo este identificado ao pai simbólico. Nesse seminário, Lacan (19561957/1995) propóe uma articulação das operaçóes da falta - castração, frustração e privação - com as categorias do simbólico, do imaginário e do real, respectivamente, e define as funções do pai nos três registros. Entretanto, no seminário seguinte, As formaçóes do inconsciente, de 1957-1958, esse ternário está aparentemente ausente e a ênfase recai sobre a metáfora paterna.

Vale ressaltar que Lacan (1956-1957/1995), no Seminário A relação de objeto, demonstrou especial interesse na análise dos casos clínicos de Freud, através dos quais retomou a problemática do pai e fez avançar sua elaboração da função paterna: "com efeito, aprendemos, desde o primeiro ano de nossos seminários, a distinguir a incidência paterna no conflito, sob o tríplice aspecto do pai simbólico, do pai imaginário e do pai real" (1956-1957/1995, p. 205).

Nesse mesmo seminário, Lacan (1956-1957/1995) afirma que, se a psicanálise atribui ao Édipo uma função normativa, a experiência nos ensina que não basta que conduza o sujeito a uma escolha objetal, não basta que alcance a heterossexualidade depois do Édipo, senão que isso tem que se dar de forma que o sujeito se situe corretamente com relação à função do pai. Este seria o centro da problemática edípica. Porém o que quer dizer esse se situar corretamente em relação à função do pai? A função do Édipo, ao menos no caso do menino, parece destinada a possibilitar a identificação do sujeito com seu próprio sexo, o que se dá na relação imaginária com o pai. Entretanto, Lacan aponta que a verdadeira meta do Édipo é “a justa situação do sujeito com referência à função do pai, isto é, que ele próprio aceda um dia a essa posição tão problemática e paradoxal de ser um pai” (Lacan, 1956-1957/1995, p. 208).

A pergunta “o que é ser um pai?” é um problema para todo neurótico, bem como para qualquer sujeito em sua experiência infantil. Além de ser uma forma de aproximar-se da questão do significante paterno, tal pergunta aponta para algo que não devemos esquecer: trata-se de que os sujeitos se convertam, eles também, 
em pais. Contudo, o que significa ser pai ninguém pode dizer: "é o jogo jogado com o pai, jogo de quem perde ganha ${ }^{2}$, se assim posso dizer, que por si só permite à criança conquistar o caminho por onde nela será depositada a primeira inscrição da lei” (Lacan, 1956-1957/1995, p. 214). Aqui se coloca o fato de que a castração permite passar do falo como objeto imaginário para o falo como objeto simbólico, o qual o menino pode conceber que lhe será dado um dia: ganha quem perde.

A assunção do signo da posição viril masculina implica como ponto de partida a castração, diz Lacan, afirmando que isso é o que nos ensina a noção freudiana do Édipo. A castração, por sua vez - se nos remetemos ao quadro das operações da falta, que Lacan (1956-1957/1995) monta ao longo desse seminário -, é uma operação simbólica que tem por objeto o falo imaginário e cujo agente é o pai real. Assim, no tocante à assunção da posição sexual do sujeito, o pai real, como agente da castração, exerce função.

No que se refere ao pai simbólico, o único que poderia responder a essa posição "é aquele que poderia dizer, como o Deus do monoteísmo: Eu sou aquele que sou" (Lacan, 1956-1957/1995, p. 214). Essa frase, contudo, ninguém pode pronunciá-la. A prova disso, Lacan diz encontrarmos em Freud, mais precisamente em "Totem e tabu". Os filhos tiveram que matar o pai como ser para demonstrar que matá-lo era impossível; em outras palavras, para conservá-lo como significante, para eternizá-lo como o pai da origem.

Lacan (1956-1957/1995) situa as instâncias do pai simbólico, do pai imaginário e do pai real como enlaçadas: uma não se dá sem a outra, é preciso as três para que tenham consistência e suas funçóes sejam efetuadas. $\mathrm{O}$ pai simbólico somente se alcança com uma construção mítica. $\mathrm{O}$ pai imaginário se refere à dialética da agressividade e da idealização através da qual o sujeito acede à identificação com o pai. Além disso, está integrado na relação imaginária, que é suporte das relaçôes com o semelhante. O pai imaginário é, ainda, o pai terrorífico el ou onipotente das experiências neuróticas. E, por ser imaginário, fantasmático, não tem obrigatoriamente qualquer relação com o pai biológico ou seu eventual substituto. Por outro lado, conforme aponta Lacan, a instância do pai real dificilmente é captada pelo menino, justamente em função da interposição dos fantasmas e da necessária relação simbólica. Entretanto, é ao pai real que Lacan confere função destacada no complexo de castração, pois essa operação está sempre vinculada à sua incidência.

Em um tempo constitutivo anterior à entrada no complexo de castração, o menino oferece-se como o falo para a mãe, pois deseja o desejo do Outro e percebe o falo como o centro do desejo materno. Em uma relação imaginária, o menino assegura à mãe que pode satisfazê-la, preenchê-la completamente em relação 
ao que lhe falta. Essa situação é estruturante, porém dá lugar à angústia quando, caindo em sua própria armadilha, o infante vê-se confrontado com a hiância que há entre corresponder a uma imagem e ter algo a oferecer. Essa situação sem saída em que se encontra o menino tem como consequência o complexo de castração.

Retomaremos adiante como isso se articula com a instância do pai real, que é o que indica para a criança, e também para a mãe, que a criança não é aquilo que falta à mãe e que o gozo dessa mulher não lhe concerne. Assim, libera - ao mesmo tempo que pró́be - a criança desse lugar de falo imaginário da mãe.

Enfim, se a castração está sempre vinculada à incidência do pai real, uma questáo se coloca: "ela pode igualmente ser marcada de uma maneira profunda, e profundamente desequilibrada, pela ausência do pai real" (Lacan, 19561957/1995, p. 226). Lacan se refere ao pai real ou ao pai da realidade? As duas noçóes parecem confundir-se. Contudo, pode-se dizer que contrasta com o que Lacan (1957-1958/1999) aborda no Seminário As formaçóes do inconsciente, onde não só diferencia o pai da realidade e a função paterna, chegando a sugerir que o primeiro não exerce, em relação à função, qualquer influência significativa, mas onde também enfatiza a dimensão simbólica e metafórica do pai.

Nesse seminário, Lacan (1957-1958/1999) pensa a intervenção do pai como a substituição de um significante por outro, ou seja, como metáfora. Assim, afirma que a metáfora paterna concerne à função do pai, a qual, por sua vez, está presentificada no centro da questâo edípica. E é justamente o complexo de Édipo que o inconsciente revela - revela os dramas do desejo e da interdição que lhe é constitutiva.

Quando falamos de Édipo a questão não passa necessariamente pela ausência ou presença concreta do pai. O Édipo pode constituir-se normalmente mesmo quando o pai da realidade não está presente. É possível “que o pai esteja presente mesmo quando não está, o que já deveria nos incitar a uma certa prudência no manejo do ponto de vista ambientalista no que concerne à função do pai" (Lacan, 1957-1958/1999, p. 173). Acrescentamos que o inverso também ocorre, como se percebe principalmente na clínica com crianças: que o pai esteja ausente (como função, no complexo) mesmo quando está presente (na realidade). Lacan aponta que a carência do pai na família não se confunde (ou não deveria ser confundida) com a sua carência no complexo.

No tocante ao Édipo, Lacan (1957-1958/1999) distingue três eixos que suscitam indagações clínicas: o Édipo em relação ao supereu, em relação à realidade (por exemplo: as estruturas da psicose e da perversão, que comportam uma subversão na relação com a realidade) e em relação ao ideal do eu. A função normativa do complexo de Édipo está relacionada com esse terceiro eixo, pois 
comporta a assunção do próprio sexo pelo sujeito; ao ser assumida, a genitalização torna-se parte do ideal do eu. Lacan afirma que o "pai intervém em diversos planos. Antes de mais nada, interdita a mãe. [...] é aí que o pai se liga à lei primordial da proibição do incesto" (Lacan, 1957-1958/1999, p. 174). Nessa perspectiva, a interdição, enquanto lei simbólica que o pai realiza, incide sobre a mãe. Trata-se da castração, um ato simbólico a partir de uma intervenção do pai real, cujo objeto é imaginário: o falo imaginário.

Embora esteja profundamente ligada a essa articulação simbólica com a lei de interdição do incesto, a castração se manifesta como uma ameaça para o menino no plano imaginário, estabelecendo, nesse plano, a rivalidade com o pai. Dito de outra forma, na neurose a ameaça de castração é vivida como uma retaliação, como uma agressáo imaginária. Isso porque o menino projeta imaginariamente no pai suas próprias tendências agressivas quando seu objeto privilegiado, a mãe, lhe é proibido. Assim, "o pai frustra o filho da posse da mãe" (Lacan, 19571958/1999, p. 178). A frustração, ato imaginário concernente a um objeto real, a mãe, tem como agente o pai simbólico.

O pai imaginário surge como agente da privação, como aquele que se faz preferir em lugar da mãe, possibilitando o estabelecimento da identificação ideal: "em outras palavras, no momento da saída normatizadora do Édipo, a criança reconhece não ter - não ter realmente aquilo que tem, no caso do menino, e aquilo que não tem, no caso da menina” (Lacan, 1957-1958/1999, p. 179). Lacan reconhece nisto um impasse, uma dificuldade na sua explicação. Buscando uma solução, questiona o que é o pai e, mais especificamente, o que ele é no complexo de Édipo. Aponta que, mesmo intervindo como real para dar corpo à castração, o pai não é um objeto real. Também não é unicamente um objeto ideal, afirma. Lacan então se refere ao pai simbólico para afirmar que o pai é uma metáfora: “a função do pai no complexo de Édipo é ser um significante que substitui o primeiro significante introduzido na simbolização, o significante materno" (Lacan, 1957-1958/1999, p. 180). No lugar do desejo da mãe, vem o significante Nome-do-Pai.

O que está em jogo não é da ordem da verdade da procriação. Dessa forma, o pai é real, mas ele só o é "na medida em que as instituições lhe conferem [...] seu nome de pai"; o que interessa é "sancionarem num significante que aquele com quem ela [a mãe] praticou o coito é o pai” (Lacan, 1957-1958/1999, p. 186-187). É nesse sentido que Lacan diz que a posição do Nome-do-Pai situa-se no nível do simbólico como uma necessidade da cadeia significante.

Retomando as relações entre a criança e sua mãe, seus termos estão resumidos no triângulo imaginário: mãe, criança e falo. Neste triângulo, não está incluído 
o pai. Entretanto, a criança nasce em uma estrutura em que já está presente, desde o início, o ir e vir da mãe. Com isso, introduz-se uma primeira simbolização; a do fort-da. Esse ir e vir leva a criança, cujo desejo é o desejo da mãe, a perguntar-se por aquilo em torno do que giram essas idas e vindas: há nela o desejo de Outra coisa. Por trás da mãe, há toda uma ordem simbólica, que faz com que seu desejo situe-se em relação ao falo. Visto que o falo é o objeto de desejo da mãe, a criança se oferece nesse lugar. É por meio dessa ordem simbólica que se introduz o termo pai em outro triângulo: o triângulo simbólico pai - mãe - filho. Dessa maneira, o pai entra no triângulo, mesmo que para a criança ele ainda não tenha entrado.

É em um segundo tempo que o pai intervém como onipotente e privador. Coloca-se em questão aí o Outro do Outro, o que para a criança retorna como a lei do pai imaginariamente concebida como privadora da mãe. No entanto, não se trata apenas de um "não te deitarás com tua mãe" dirigido à criança, mas da mensagem endereçada à mãe: "não reintegrarás teu produto". $\mathrm{O}$ pai é aqui suporte da lei, porém mediado pela mãe, a qual o instaura nesse lugar de quem lhe faz lei.

Em um terceiro tempo, o pai não mais intervém como aquele que é o falo, mas sim como aquele que tem o falo, possibilitando "uma báscula que reinstaura a instância do falo como objeto de desejo da mãe, e não apenas como objeto do qual o pai pode privar” (Lacan, 1957-1958/1999, p. 200). Aí se dá a saída do Édipo: a identificação com o pai, mediante a constituição do ideal do eu, é feita nesse tempo. $\mathrm{O}$ menino sai com títulos de posse no bolso, para poder servir-se deles no futuro, a fim de reclamar o direito à virilidade. Já para a menina, isto não se faz necessário; basta-lhe saber onde ele está e ir buscá-lo.

Entretanto, cabe ressaltar que no seminário As formaçóes do inconsciente (Lacan, 1957-1958/1999) a ênfase recai sobre a função simbólica do pai, sobre o pai como metáfora, como Nome-do-Pai, significante que, na cadeia, vem acima dos demais, organizando-os. Trata-se do pai ligado à enunciação da lei. E isso é introduzido pelo lugar e peso que a mãe dá à palavra do pai:

Ora, trata-se menos das relaçóes pessoais entre o pai e a mãe, ou de saber se ambos estão ou não à altura, do que de um momento que tem que ser vivido como tal, e que concerne às relaçóes não apenas da pessoa da mãe com a pessoa do pai, mas da máe com a palavra do pai - com o pai na medida em que o que ele diz não é, de modo algum, igual a zero (Lacan, 1957-1958/1999, p. 197).

Para que se inscreva o Nome-do-Pai, não é preciso o pai da realidade. A mãe introduz a metáfora paterna com o lugar que dá à palavra do pai. A função 
paterna depende então desse único alicerce? Quando a mãe não dá lugar em seu discurso para essa função simbólica, podem outras instâncias co-operar para que a palavra do pai adquira valor? Quando se torna necessário o pai da realidade? A forma como ele se apresenta seria completamente indiferente para o filho?

Após o seminário As formaçóes do inconsciente, durante o período de 1958 a 1963, nenhum dos seminários proferidos por Lacan ( $O$ desejo e sua interpretação, A ética da psicanálise, A transferência e $A$ identificação) aborda o Nome-do-Pai ou o ternário pai simbólico, imaginário e real, salvo poucas exceçóes. Esse período corresponde ao questionamento da IPA da demanda de adesão feita pela SFP (Sociedade Francesa de Psicanálise), da qual Lacan era membro. Para obter o reconhecimento da IPA, o preço a ser pago pela SFP era não mais reconhecer Lacan como didata.

Em função de sua excomunhão (como nomeou o próprio Lacan), em novembro de 1963, Lacan decide interromper o seminário que havia anunciado para aquele ano e para o ano subsequente: Os nomes do pai. Essa suspensão seria lembrada reiteradamente por Lacan. De acordo com Porge (1998, p. 88), essa reiteração seria "um modo de fazer ato desta interrupção, de fazer disto um dizer, um dizer não, não haverá o seminário Os nomes do pai”; "é um modo de dizer, em ato, algo que concerne ao Nome-do-Pai”.

Em 20 de novembro de 1963, Lacan (1963/2007) deu a primeira e única aula desse seminário. Nesta, referindo-se à decisão de se deter, comenta algumas aulas de seminários de seu ensino anterior, as quais pretendia enlaçar nesse seminário que não aconteceu. Entre essas estão as aulas referentes à metáfora paterna e ao complexo de Édipo do seminário As formaçóes do inconsciente. Nessa única aula, Lacan retorna ao mito de Totem e tabu e trabalha questôes relativas à religiáo e à tradição judaico-cristá. Destacamos a seguir um ponto referente à interrogação de Freud sobre o pai e à relação desta com a psicanálise atual:

Freud coloca no centro de sua doutrina o mito do pai, claramente devido à inevitabilidade dessa pergunta. Resulta igualmente claro que se hoje parece que a teoria e a práxis da psicanálise estão detidas, é por não haver ousado ir mais longe do que Freud sobre essa pergunta (Lacan, 1963/2007, p. 84$)^{3}$.

Tomando a interrupção do seminário de 1963 como marco, Porge (1998) distingue três períodos da obra de Lacan no que se refere ao Nome-do-Pai. Um primeiro período vai de 1964 a 1969, durante o qual Lacan praticamente não fala em Nome-do-Pai, mas faz sempre lembrar a suspensão de seu seminário. Ele se conclui 
em De um Outro ao outro, quando Lacan, além de pontuar um percurso com o sujeito suposto saber e nomeando o S2 como saber, pôe-se a falar do Nome-do-Pai longamente. Um segundo período vai de 1969-1970 ( $O$ avesso da psicanálise) a 1974-1975 (RSI). Lacan segue falando do seminário interrompido em termos eloquentes, mas deixa de se abster em falar dos nomes do pai como no primeiro período. Culmina em uma solução para o problema da articulação do Nome-do-Pai e do RSI e na retomada do plural nomes do pai. Para Porge (1998), pode-se falar em solução, pois o terceiro período, de 1975-1976 (Sinthome) a 1979-1980 (Dissolução), é marcado pelo fato de Lacan continuar a falar sobre o Nome-do-Pai, porém não mais se referindo publicamente ao seminário suspenso em 1963.

Acreditamos que a articulação entre o Nome-do-Pai e o RSI é de extrema relevância no percurso dos questionamentos deste trabalho. A esse respeito, Lacan (1974-1975/2002, p. 15 da aula de 11/02/1975) comenta:

Este ano formularei, se assim posso dizer, a questão de saber se, quanto a isso de que se trata, a saber, o enodamento do Imaginário, do Simbólico e do Real, seria necessária essa função suplementar de um toro a mais, aquele cuja consistência haveria que referir à funçáo que se diz do pai. É precisamente por que essas coisas me interessavam desde há muito tempo, ainda que nessa época eu não havia encontrado esta maneira de figurá-las, que comecei (meu seminário) Os nomes do pai.

Em RSI, o Nome-do-Pai é identificado por Lacan (1974-1975/2002) como uma quarta consistência no nó borromeano: "o plural os nomes do pai, aos quais são identificados real, simbólico e imaginário, significa esta conjugação, cujo operador é o Nome-do-Pai" (Porge, 1998, p. 160). Além disso, o Nome-do-Pai sofre uma mudança de sentido, suportada pelo furo do nó borromeano, passando a representar náo apenas o nome dado ao pai, como também o pai como nomeante, quer dizer, o nome dado pelo pai. Assim, o quarto elo é suporte de uma função de nominação.

Nesse sentido, ao longo de seu ensino Lacan promove uma passagem do mito (de Édipo) à lógica, chegando a delimitar a especificidade da função nominante do pai, o que reafirma não só o nome dado pelo pai ao filho, mas também o nome que faz dele mesmo pai. Para que um sujeito seja pai, é preciso que seja nomeado pai, fazendo com que seu desejo perca o anonimato (Flesler, 2007). Conforme as formulaçóes a que Lacan chega em RSI, pode-se dizer que se reacomodam as instâncias real, simbólico e imaginário no que se refere ao seu peso na função paterna - ou, para usar o termo desse seminário, nos nomes do pai. 
Contudo, a pergunta pelo pai na forma "o que é ser um pai?" segue não podendo ser respondida, pois o que significa ser pai ninguém pode dizer. Julien (1993) observa que, formulada em termos ontológicos, tal pergunta não pode comprovar outra coisa senão uma decadência ou insuficiência: o discurso social sustenta cada vez menos o ser-pai; no século XX, observa-se um declínio social da paternidade. $\mathrm{O}$ autor não situa isso como sendo motivo para alegria ou lamento. Ele postula que a psicanálise se coloca em outro lugar e, em vez da pergunta pelo ser-pai, aponta para outra: o que é ter tido um pai? Acrescenta que é o analisante, se quiser, quem pode respondê-la. Julien coloca três dimensões através das quais se acede à filiação - o pai como nome, o pai como imagem e o real do pai - funçóes essas que se desdobram sucessivamente. Já De Neuter (1998, 2004), além de pensar as funçóes do pai simbólico, do pai imaginário e do pai real, acrescenta a necessidade de distinguir pai real e pai da realidade.

Os pais da realidade, também chamados algumas vezes por Lacan de pais concretos, são aqueles que encarnam as funçóes paternas. Evidentemente, nem sempre são os genitores

[...] aqueles que encarnam, na realidade da vida de um sujeito, as funçóes ou as instâncias de pai simbólico, de pai imaginário e de pai real. Os pais concretos efetuam essas funçóes paternas, com efeito, [...] principalmente em função de sua estrutura, suas identificações e seus sintomas (De Neuter, 2004, p. 58).

Nesse sentido, suas palavras, seus silêncios e seus atos não são sem efeito. A forma como estão estruturados os pais da realidade define o modo como poderão ou não dar suporte a essas funçóes. E isso repercute principalmente na clínica com crianças que, como ressalta Giongo (2005, p. 68), "nos mostra o quanto difícil pode ser constituir-se como sujeito sem contar com pais da realidade que deem suporte a isso".

Lacan algumas vezes utilizou o termo pais reais. A utilização desse termo para referir-se aos pais da realidade pode levar a confundir a função pai real com seus agentes - quando se fala de pai real, não se trata nem do pai da realidade, nem do genitor. Além de não salientar as diferenças que os termos comportam, De Neuter (2004) alerta que a denominação pais reais pode levar alguns leitores a crer que aí reside algo da ordem de uma verdade da paternidade. E, no entanto, pai real é aquele que introduz a impossibilidade de saber no que se refere à paternidade (Julien, 1993). Pater semper incertus est, verdade reconhecida por Freud e Lacan, remete a que o pai é um referente que não é garantido por uma verdade 
da experiência; e, por ser o pai em sua natureza incerto, há a necessidade do registro da nominação (Porge, 1998). Aqui, essa função relaciona-se à dimensão simbólica.

O pai real é aquele que introduz para a criança a castração simbólica, um dizer não: "não, tu não és o que falta à tua mãe; não, o gozo desta mulher não te concerne, não é assunto teu”. Nesse sentido, o pai real "[...] é aquele que deve responder à criança. Ele proíbe, mas mais essencialmente, ele diz. E importa o que ele diz [...] seu dizer tem efeitos, tanto sobre a criança como sobre a mãe" (De Neuter, 2004, p. 59). No entanto, é fundamental não confundir o pai real com suas encarnaçóes. O pai real pode estar encarnado no pai da realidade, mas, antes de tudo, ele opera na mãe, opondo limites ao seu gozo do filho. O fundamental é que a mãe tenha, em seu corpo, a marca da interdição. É isso que permite à criança aceder à renúncia de ser o falo da mãe. Desde essa perspectiva, a função do pai real pode encontrar-se encarnada em todo aquele que se interpóe como terceiro entre a mãe e a criança.

Em relação à dimensão simbólica do pai, sua definição teve certa variaçâo ao longo do ensino de Lacan. De Neuter (2004, p. 59), a partir do quadro proposto em As relaçóes de objeto e levando em conta comentários posteriores do mesmo, propóe pensar o "pai simbólico como a instância que traz para a criança a frustração do seio, a língua (dita materna) e o nome, sinal da adoçáo”. Ainda segundo o autor, encontra-se em Lacan uma concepção de Pai simbólico que engloba as três instâncias e equivale ao Nome-do-Pai. E, considerando a importância do lugar reservado ao pai na palavra da mãe, a função materna também se vê atravessada por essa dimensão simbólica.

Com efeito, abrir a porta para o exercício da função paterna é um aspecto privilegiado da função materna (Coriat, 2006). De acordo com Julien (1993), o pai como nome é originariamente instaurado pela mãe, a qual inscreve um lugar na ordem simbólica, lugar vazio, que um homem poderá ocupar a sua maneira. Trata-se de um lugar terceiro. A substituiçâo do significante do desejo materno, enigmático para a criança, pelo significante Nome-do-Pai engendra como significado o falo - significante da falta na mãe, o Outro primordial. Assim, a substituição de um significante por outro leva à produção de um sentido. Quando há foraclusão desse significante Nome-do-Pai, quando este não responde diante de uma injunção fálica, deparamo-nos com uma psicose.

A instância do pai simbólico é aquela que prescreve a castração mediante a intervenção do pai real e, assim, protege a criança da psicose. Portanto, está em interdependência com a função real do pai. E também em interdependência com a função do pai imaginário, que contribui para a efetuação da função simbólica, 
na medida em que é por meio da imagem do pai que a criança vive o complexo de castração.

Quando falamos de pai imaginário ou do pai como imagem, trata-se do pai construído imaginariamente pela criança a partir de seus fantasmas, desejos, experiências concretas e, também, a partir do imaginário cultural. Até o momento do declínio do Édipo e da constituição do supereu, a criança recobre o pai real com o manto de um pai imaginário - manto este que vela um gozo inominável do pai. Constrói uma imagem digna de ser admirada; como já dizia Freud, a criança promove uma exaltação da imagem do pai. Este pai imaginário é, além disso, promovido como digno de ser amado. É por essa via que se dá a identificação no declínio do Édipo, quando a criança traduz em imagens um valor simbólico.

Entretanto, essa imagem construída do pai se faz necessária ainda antes do momento do declínio do complexo de Édipo, para fazer uma espécie de contrapeso ao desejo da mãe. A criança encontra-se com sua impotência ao tentar dar conta de preencher a falta da mãe. Então, que essa carência seja proveniente do pai, deste pai poderoso, tão poderoso que seja ele a única causa da privação da mãe! Corresponde à figura de um amo que sustente e garanta a lei edípica; é um pai que faz a lei (não é seu representante) e que faz sentir sua incidência castradora. Relaciona-se, também, com o pai todo-poderoso do mito de Totem e tabu. E isso se repete na figura que cada filho cria no seu declínio do Édipo.

Aqui se coloca uma articulação clínica extremamente importante em relação ao pai imaginário. De acordo com Julien (1993), é o pai como imagem o objeto do trabalho analítico. Não se deve analisar o pai real, mas o véu posto diante dele $e^{4}$ Se esse pai como imagem é fundado como amo, também é alçado como criador do filho, como responsável pelo que é o filho, tanto quanto pelo que ele não é. E, se o filho não é algo, é porque esse pai não o quis. Essa espécie de censura continua enquanto não se realiza o luto por esse pai idealizado. Porém, para abrir mão do amor pelo poder desse pai, o sujeito tem que passar primeiro por um momento de ódio contra ele. $\mathrm{O}$ analisante descobre, justamente, que o luto por esse pai ocorre pelo reconhecimento de seu ódio por ele. A dimensão do pai real opera nesse ponto, permitindo o luto do pai ideal. Na experiência analítica, é preciso que o analista não se coloque como amo para possibilitar ao sujeito a análise do manto que é o pai imaginário que recobre o pai real.

Importa agora retomar o recorte que deu lugar aos interrogantes que nos lançaram à escrita deste artigo. Sabemos que um Édipo pode constituir-se muito bem mesmo quando o pai da realidade não está presente. $\mathrm{O}$ rumo da estruturação psíquica de um sujeito não depende necessariamente da presença dos genitores. 
Entretanto, depende, e muito, de que haja alguém que venha encarnar as funçóes materna e paterna. Dessa forma, no caso de Pablo, a questão não girava simplesmente em torno da ausência do pai biológico; podemos dizer que fazia falta a presença do pai no complexo. Não havia quem o encarnasse, quem pudesse dar corpo às instâncias da função paterna.

A palavra do pai não foi introduzida pelo discurso da mãe até a chegada de Gonzalo. Aliás, até esse momento a mãe não sabia que precisava falar com seu filho; este, por sua vez, apresentava sérias dificuldades de linguagem. Assim, o silêncio da mãe não foi sem efeitos. Foi preciso a entrada desse homem, em um lugar terceiro, que não só fizesse corte, colocando limites ao gozo da mãe, mas que fizesse valer sua palavra, para possibilitar uma série de coisas. Por exemplo, Pablo passa a ter um espaço seu; quem dorme na cama da mãe agora é Gonzalo. A esse respeito, Coriat (2006, p. 79) afirma:

[...] a quem cabe encarnar a sustentação corporal da lei primitiva é ao pai. O sistema mais eficaz [...] é que o pai volte a se fazer desejar pela mulher que foi mãe de seu filho. Não há argumento melhor para tirar um bebê da cama que deseja compartilhar com a mulher. Claro que nem sempre é possível, não depende somente dele; porém, que ao menos sua presença esteja posta de maneira tal que recorde à mãe que há outros gozos nesse mundo mais além do maravilhoso bebê.

Ainda que não se trate do pai biológico de Pablo, Gonzalo exerce essa função. Em contrapartida, para Soledad seu bebê não era tão maravilhoso assim... A intervenção desse homem possibilita que mãe e filho se desgrudem e que o menino possa sair para brincar com outras crianças. O dizer desse pai tem efeitos tanto sobre a criança como sobre a mãe. Pablo se interessa pela palavra de Gonzalo, a qual tem um lugar no discurso da mãe. Assim, tornam-se possíveis as funçōes do pai real, simbólico e imaginário e as operações que estas instâncias realizam $^{5}$. Retornamos aqui a uma das questôes lançadas ao início deste artigo: afinal, o que transmite um pai? De que transmissão se trata quando falamos no pai enquanto função?

O que o pai transmite ao filho, por intermédio das instâncias e operaçōes já mencionadas, é, fundamentalmente, a filiação, a lei e, consequentemente, o desejo. Tal transmissão, regulada pela castração, é essencial para que o infante aceda à condição de sujeito desejante, é condição da economia desejante (Flesler, 2007). O pai, ao colocar-se como desejante, ao fazer de uma mulher causa de seu desejo, também se coloca em falta e alude a uma perda de gozo; desse modo, doa 
sua castração. Somente assim "consegue oferecer a transmissão do desejo e está em condiçóes de criar um véu que desperte a ânsia de saber" (Flesler, 2007, p. 50). Se o desejo da mãe realiza antecipadamente a sustentação narcísica da criança, o desejo do pai será promotor de uma operação nominante que efetiva um enlace. Os nomes do pai, articulados sob a forma do nó borromeano, ganham consistência no limite que encontram um no outro. E é a consistência entendida desse modo que faz do pai o transmissor da lei do desejo.

Se o pai é transmissor da lei do desejo, ele o é, também, da sua própria incerteza - pater incertus est. E, porque houve castração, no lugar dessa incerteza não advém certeza, mas a ficção, a ilusão e os ideais. A função do pai comporta transmitir o impossível de uma garantia dos fatos, transmitir a origem enquanto perdida. Assim, podemos estabelecer a transmissão da ficção como algo que também concerne a um pai (Rickes, 2005).

Do percurso que desenvolvemos aqui, o que podemos destacar a título de conclusão?

$\mathrm{Na}$ experiência analítica, desde Freud até os dias de hoje, a pergunta pelo pai permanece central. Ainda que Freud tenha situado o pai como preeminente na constituição da realidade psíquica, foi necessária a construção de um mito (Totem e tabu) para dar conta disso que, de acordo com a leitura lacaniana, permanecia como hiância na doutrina freudiana. Lacan retomou a interrogação de Freud e buscou respondê-la ao longo de seu ensino, introduzindo os termos pai simbólico, pai imaginário e pai real, metáfora paterna, Nome-do-Pai e, posteriormente, o plural nomes do pai. Os deslocamentos, às vezes sutis, entre esses termos em diferentes momentos da teorização lacaniana - os quais buscamos desdobrar ao longo do artigo - não são sem consequência para a clínica.

A elaboração de Lacan sobre a função paterna é atravessada, desde o primeiro ano de seus seminários, pela referência aos casos clínicos de Freud. A propósito desses, Lacan sempre mencionou a incidência paterna no conflito. Isso evidencia a importância clínica da função paterna, ou melhor, a importância das articulações que aí podem se produzir.

No meio psicanalítico, costuma-se enfatizar a relevância da linguagem como terceiro simbólico, do papel da mãe na introdução da metáfora paterna, do Nome-do-Pai como significante... Estas formulações são, evidentemente, fundamentais na teoria e na clínica psicanalíticas. Entretanto, são por vezes utilizadas de tal forma, que se incorre no risco de um esquecimento ou de um esvaziamento de outros registros que entram em jogo na constituição do sujeito, como as dimensóes real e imaginária do pai. Também se costuma obliterar o fato de que é preciso que alguém encarne, dê corpo, exerça essas funçóes. 
A estrutura do sujeito, conforme Lacan formulou ao final de seu ensino, é a estrutura tripartida R.S.I., na forma do nó borromeano. $\mathrm{O}$ enlace dos três registros supóe algumas leis, que têm como consequência o fato de, ao se cortar qualquer um dos três, desarmar-se a estrutura toda, pois se separam os demais. Isso implica que o sujeito não é estruturado somente pelo simbólico, nem apenas pelo imaginário, tampouco unicamente pelo real. Os três registros, enlaçados dessa maneira, formam uma única estrutura, encontrando cada um limite nos outros dois.

Assim, se a estrutura do sujeito é RSI, não podemos desconsiderar ou privilegiar uma ou outra dessas dimensóes. Do mesmo modo que, se cortamos um dos registros desprendem-se os três anéis, também as instâncias do pai real, simbólico e imaginário - ou os nomes do pai - são interdependentes para sua efetuação e consistência. Na clínica, portanto, é crucial considerar as diferentes instâncias do pai, o lugar que ocupam na estrutura e as operaçóes necessárias que efetuam nos tempos de constituição do sujeito.

\section{Referências}

Bergès, J. \& Balbo, G. (2002). Jogo de posiçôes da mäe e da criança: ensaio sobre o transitivismo. (A. Vorcaro, N. V. A. Leite, V. Veras, Trad.). Porto Alegre: CMC Editora.

Coriat, E. (2006). El psicoanálisis en la clínica de niños pequeños con grandes problemas. Buenos Aires: Lazos.

Costa, A. (2001). Corpo e escrita: relaçôes entre memória e transmissão da experiência. Rio de Janeiro: Relume Dumará.

De Neuter, P. (1998). Pai real, incesto e devir sexual da menina (M. Veras, Trad.). In A. B. Teixeira (Org.). O sujeito, o real do corpo e o casal parental (2a ed., pp. 183-215). Salvador: Ágalma.

De Neuter, P. (2004). Mal estar na paternidade. (M. Alves, Trad.). Revista da Associação Psicanalitica de Porto Alegre, 11(27), 57-77.

Flesler, A. (2007). El niño en análisis y el lugar de los padres. Buenos Aires: Paidós.

Freud, S. (2006a). La novela familiar del neurótico. (L. Torres, Trad.). In Obras completas de Sigmund Freud, v. IV ( $3^{\mathrm{a}}$ ed.). Madrid: Biblioteca Nueva. (Trabalho original publicado em 1909)

Freud, S. (2006b). Tótem y tabú. (L. Torres, Trad.). In Obras completas de Sigmund Freud, v. V ( $3^{a}$ ed.). Madrid: Biblioteca Nueva. (Trabalho original publicado em 1913)

Giongo, A. (2005). Ex-Pai? Revista da Associação Psicanalítica de Porto Alegre, 13(28), 61-70. Julien, P. (1993). El manto de Noé: ensayo sobre la paternidad. (A. Magaldi \& P. Guthmann, Trads.). Buenos Aires: Alianza Editorial. 
Lacan, J. (1995). O seminário, livro 4: a relaçâao de objeto. (D. Estrada, Trad.). Rio de Janeiro: Jorge Zahar. (Trabalho original de 1956-1957)

Lacan, J. (1999). O seminário, livro 5: as formaçôes do inconsciente. (V. Ribeiro, Trad.). Rio de Janeiro: Jorge Zahar. (Trabalho original de 1957-1958)

Lacan, J. (2002). El seminario, libro 22: R.S.I. (R. Ponte, Trad.). Buenos Aires: Escuela Freudiana de Buenos Aires. (Trabalho original de 1974-1975)

Lacan, J. (2007). De los nombres del padre. (N. González, Trad.). Buenos Aires: Paidós.

Porge, E. (1998). Os nomes do pai em Jaques Lacan: pontuaçóes e problemáticas (C. Almeida, Trad.). Rio de Janeiro: Companhia de Freud.

Rickes, S. (2005). Notas sobre a transmissão da diferença. Revista da Associação Psicanalítica de Porto Alegre 13(28), 113-120.

\section{Notas}

${ }^{1}$ A grafia Nome-do-Pai, com hífens e maiúsculas nos dois termos, é empregada nos textos escritos por Lacan, exceto no Discurso de Roma. Escrito dessa forma, ressalta a unidade entre nome e pai, sem dar preeminência a um ou outro termo (Porge, 1998; Flesler, 2007).

${ }^{2}$ Em todas as citaçóes, os grifos que aparecem são os que constam nas obras utilizadas.

${ }^{3}$ Todas as traduçóes de obras publicadas em língua estrangeira e citadas neste artigo são de nossa responsabilidade.

${ }^{4}$ Isso deve ser circunscrito à clínica com adultos, pois na infância a presença desse véu dá consistência ao eu infantil.

${ }^{5}$ Entretanto, diante das dificuldades de linguagem que Pablo apresenta, a continuidade de um espaço de tratamento psicanalítico poderia vir em apoio aos tempos e operaçóes estruturantes da constituição subjetiva desse menino.

Recebido em 19 de julho de 2012 Aceito para publicação em 26 de abril de 2013 